\title{
ISLAM DAN HAK ASASI MANUSIA
}

\author{
Sahliah \\ Program Studi Muamalah, Fakultas Syariah, UIN Sumatera Utara \\ sahliah13@gmail.com
}

\begin{abstract}
Islam is a religion that is blessed by Allah. Islam regulates all rules in human life. Islam really respects basic human rights which are the rights that are obtained since humans are born. The aim of this research is to describe human rights in the perspective of Islam. This study used a library research and the techniques used in analyzing the data were data reduction, data presentation and data verification. The study finds out that in Islam, human rights have strong sources. Such as in The Koran, many of verses describes about value of Human rights. The finding of this study can increase our understanding about human right seen from Islamic perspective.
\end{abstract}

Keywords: Islam, Human, Human Rights.

\section{A. Pendahuluan}

Hak asasi manusia atau biasa disingkat HAM merupakan sebuah hal yang menjadi keharusan dari sebuah negara untuk menjaminnya dalam konstitusinya. HAM adalah seperangkat hak yang melekat pada hakikat keberadaan manusia sebagai makhluk Tuhan Yang Maha Esa yang merupakan anugerah-Nya yang wajib dihormati, dijunjung tinggi dan dilindungi oleh negara, hukum, pemerintah, dan setiap orang demi kehormatan serta perlindungan harkat dan martabat manusia dalam Pasal 1 butir 1 UU no. 39 Th. 1999 tentang HAM dan pasal 1 butir 1 No.26 Th. 2000 tentang pengadilan HAM (Bambang, 2006). Melalui deklarasi universal HAM 10 Desember 1948 merupakan tonggak bersejarah berlakunya penjaminan hak mengenai manusia sebagai manusia. Sejarah HAM dimulai dari magna charta di Inggris pada tahun 1252 yang kemudian berlanjut pada bill of rights dan kemudian berpangkal pada DUHAM PBB. Dalam konteks keIndonesiaan penegakan HAM masih bisa dibilang kurang memuaskan. Banyak factor yang menyebabkan penegakan HAM di Indonesia terhambat seperti problema politik, dualisme peradilan dan prosedural acara.

Islam sebagai agama bagi pengikutnya meyakini konsep Islam adalah sebagai way of life yang berarti pandangan hidup. Islam menurut para penganutnya merupakan konsep yang lengkap mengatur segala aspek kehidupan manusia. Begitu juga dalam pengaturan mengenai hak asasi manusia Islam pun mengatur mengenai hak asasi manusia. Islam adalah agama rahmatan lil 'alamin yang berarti agama rahmat bagi seluruh alam. Bahkan dalam ketidakadilan sosial sekalipun Islam pun mengatur mengenai konsep kaum mustadh'afin yang harus dibela.

Dalam Islam, konsep mengenai HAM sebenarnya telah mempunyai tempat tersendiri dalam pemikiran Islam. Perkembangan wacana demokrasi 
dengan Islam sebenarnya yang telah mendorong adanya wacana HAM dalam Islam. Karena dalam Demokrasi, pengakuan terhadap hak asasi manusia mendapat tempat yang spesial. Berbagai macam pemikiran tentang demokrasi dapat dengan mudah kita temukan didalamnya konsep tentang penegakan HAM.

Bahkan HAM dalam Islam telah dibicarakan sejak empat belas tahun yang lalu (Anas Urbaningrum, 2004:9). Fakta ini mematahkan bahwa Islam tidak memiliki konsep tentang pengakuan HAM. Sejarah awal hak asasi manusia di barat berkembang sejak tahun 1215 yaitu dalam Magna Charta yang berisi aturan mengenai tindakan dan kebijakan negara supaya tidak berjalan sewenang-wenang. Isi dari Magna Charta ialah bermaksud untuk mengurangi kekuasaan penguasa. Usaha untuk diadakannya Magna Charta ini dimulai dari perjuangan tuan tanah dan gereja untuk membatasi kekuasaan raja dan para anggota keluarga. Pada priode awal ini hubungan antara isi dasar HAM adalah mengenai (hubungan) antara anggota masyarakat yang berada dibawah kekuasaan yang diatur kebendaannya.

Sekelompok tuan tanah dan ksatria menggalang kekuatan dan mereka berhasil mendesak raja untuk tidak lagi memberlakukan tindakan penahanan, penghukuman dan perampasan benda benda secara sewenang-wenang. Raja Jhon terpaksa menyetujui tuntutan ini dengan memberikan cap pengesahan yang berlangsung pada juni 1215 di Runnymede, sebuah padang rumput di pinggir sungai Thames. Isi dari Magna Charta ini ada tiga. Pertama, raja dilarang menarik pajak sewenang-wenang. Kedua, pejabat pemerintah dilarang mengambil jagung dengan tanpa membayar. Dan yang ketiga, tidak seorang pun dapat dipenjara tanpa saksi yang jelas. Pengesahan ini menjadi dokumen tertulis yang pertama tentang hak-hak tuan tanah, gereja, ksatria dan orang merdeka atau orang sipil yang belum menikmati kebebasan.

Berlanjut setelah keberhasilan tuan tanah, bangsawan dan orang merdeka untuk memperjuangkan hak-hak mereka di hadapan raja membangkitkan kesadaran diberbagai kalangan masyarakat terhadap pentingnya hak-hak untuk dihormati dan dilindungi. Pada tahun 1628, kaum bangsawan menuntut hak-hak mereka kepada raja. Mereka mencetuskan Petition of Right. Yang menuntut sebuah negara yang kostitusional, termasuk didalamnya fungsi parlemen dan fungsi pengadilan. Jhon Locke (1632-1704) bersama Lord Ashley merumuskan tuntunan bagi toleransi beragama. Selain itu, juga menyatakan bahwa semua orang diciptakan sama dan memiliki hak-hak alamiah yang tidak dapat dicabut seperti hak untuk hidup, kemerdekaan, hak milik dan hak untuk meraih kebahagiaan.

Salah satu karya Locke yang terkenal ialah second treaties on civil government yang berisi mengenai negara atau pemerintah harus berfungsi untuk melindungi hak milik pribadi. Pemerintah dibentuk guna menjamin kehidupan, harta benda dan kesejahteraan rakyat. Gagasan Locke ini sesuai dengan perkembangan didalam masyarakat Inggris yang mulai berubah dari negara kerajaan yang absolute menuju kerajaan yang konstitusional. 
Pada 1653 instrument of government berhasil disahkan. Pembatasan kekuasaan raja semakin dikukuhkan dengan lahirnya Habeas Corpus Act pada Mei 1679. Lonceng kebebasan terus berdentang dan pada 16 Desember 1689 Bill Of Rights lahir. Mereka tidak hanya berhasil membebaskan diri dari kesewenangan raja. Dan mereka juga berhasil membentuk parlemen yang mempunyai kewenangan untuk mengontrol kekuasaan raja. Semua hak-hak yang ada dalam berbagai instrument HAM tersebut kemudian dijadikan dasar pemikiran untuk melahirkan rumusan HAM yang bersifat universal, yang kemudian dikenal dengan The Universal Declarations of Human Rights yang disahkan oleh PBB pada tahun 1948.

Dalam perspektif Islam sebagai mana yang dikonsepsikan Alquran, Hak Asasi Manusia bersesuaian dengan Hakhak Allah swt (Siti, 2010). Berangkat dari itu tulisan ini akan mendeskripsikan bagaimana Konsep Islam dan Hak Azasi Manusia.

Penelitian ini menggunakan metode kualitatif. Penelitian ini juga merupakan penelitian kepustakaan (Library Research) dengan menggunakan metode analisis deskriptif. Library research adalah serangkaian kegiatan yang berkenaan dengan metode pengumpulan data pustaka (Mahmud, 2011). Teknik analisis data yang digunakan menggunakan adalah data reduksi, penyajian data dan kesimpulan.

\section{B. Hasil dan Pembahasan}

\section{HAM dalam Islam}

Islam sebagai agama universal membuka wacana signifikan bagi HAM. Tema-tema HAM dalam Islam, sesungguhnya merupakan tema yang senantiasa muncul, terutama jika dikaitkan dengan sejarah panjang penegakan agama Islam. Menurut Syekh Syaukat Hussain yang diambil dari bukunya Anas Urbaningrum, HAM dikategorikan dalam dua klasifikasi. Pertama, HAM yang didasarkan oleh Islam bagi seseorang sebagai manusia. Dan kedua, HAM yang diserahkan kepada seseorang atau kelompok tertentu yang berbeda. Contohnya seperti hak-hak khusus bagi non-muslim, kaum wanita, buruh, anak-anak dan sebagainya, merupakan kategori yang kedua ini (Anas, 2004).

Yang pertama adalah hak negatif yaitu memberikan kebebasan kepada manusia dalam pemenuhannya. Beberapa yang dapat kita ambil sebagai contoh yaitu:

a. Hak atas hidup, dan menghargai hidup manusia. Islam menegaskan bahwa pembunuhan terhadap seorang manusia ibarat membunuh seluruh umat manusia. Hak ini terkandung dalam surah Al-Maidah ayat 32 yang berbunyi :

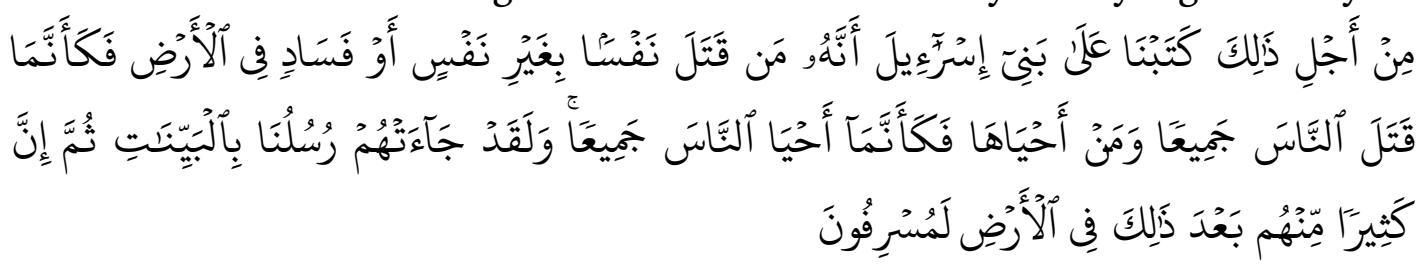

Artinya: 
"Oleh karena itu kami tetapkan (suatu hokum) bagi bani israil, bahwa: barang siapa yang membunuh seseorang manusia, bukan karena orang itu (membunuh) orang lain, atau bukan karena membuat kerusakan di muka bumi, maka seakan-akan dia telah membunuh manusia seluruhnya. Dan barang siapa yang memelihara kehidupan seorang manusia, maka seolah-olah dia telah memelihara kehidupan manusia semuanya. Dan sesungguhnya telah dating kepada mereka rasul-rasul Kami dengan (membawa) keterangan-keterangan yang jelas, kemudian banyak diantara mereka sesudah itu sungguh-sungguh melampaui batas dalam berbuat kerusakan dimuka bumi. (QS Al-Maidah:63)

b. Hak untuk mendapat perlindungan dari hukuman yang sewenang-wenang. Yaitu dalam surat Al-An'am ayat 164 yang berbunyi:

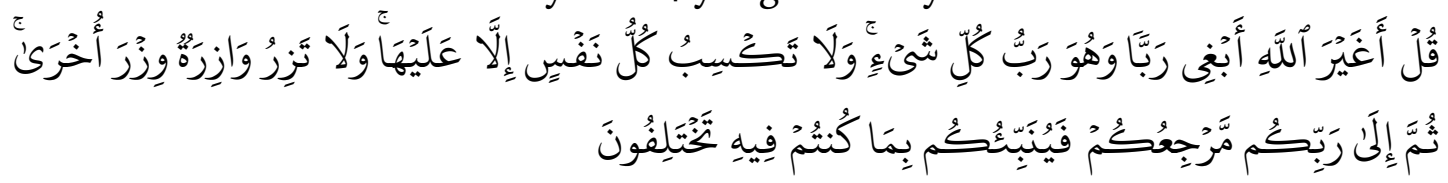

Artinya:

"Katakanlah:"Apakah aku mencari Tuhan selain Allah, padahal Dia adalah Tuhan bagi segala sesuatu. Dan tidaklah seseorang membuat dosa melainkan kemudharatannya kembali kepada dirinya sendiri; dan seorang yang berdosa tidak akan memikul dosa orang lain. Kemudian kepada Tuhanmulah kamu kembali, dan akan diberitakan-Nya kepadamu apa yang kamu perselisihkan". (QS Al-An'am: 164)

c. Hak atas keamanan dan kemerdekaan pribadi terdapat dalam surat AlHujurat: 6 yang berbunyi:

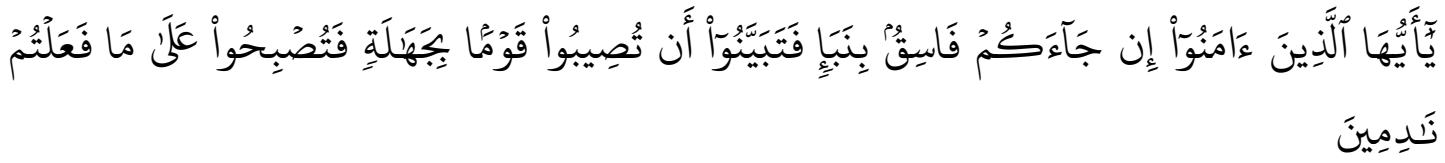

Artinya:

"Hai orang-orang yang beriman jika datang kepadamu orang yang fasik membawa suatu berita, maka periksalah dengan teliti, agar kamu tidak menimpakan suatu musibah kepada suatu kaum tmengetahui keadaannya yang menyebabkan kamu menyesal atas perbuatan itu". (QS Al-Hujurat: 6)

d. Hak atas kebebasan beragama memilih keyakinan berdasar hati nurani. Yang bisa kita lihat secara tersirat dalam surat Al-Baqarah ayat 256 yang berbunyi:

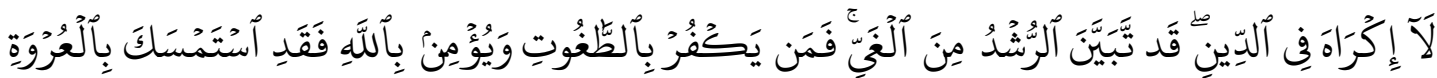

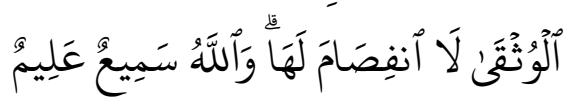

Artinya:

"Tidak ada paksaan untuk (memasuki) agama (Islam); sesungguhnya telah jelas jalan yang benar daripada jalan yang sesat. Karena itu barangsiapa yang ingkar kepada yang thagut dan beriman kepada Allah, maka sesungguhnya ia 
telah berpegang kepada buhul tali yang amat kuat yang tidak akan putus. Dan Allah Maha Mendengar lagi Maha Mengetahui”. (QS Al-Baqarah: 256)

e. Hak atas persamaan hak didepan hukum secara tersirat terdapat dalam surat An-Nisa ayat 1 yang berbunyi:

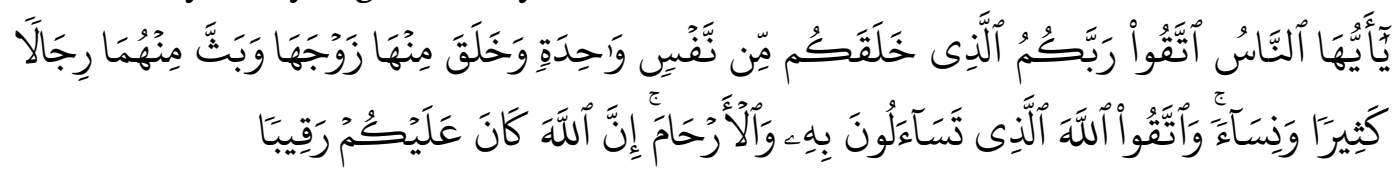

Artinya:

"Hai sekalian mausia bertaqwalah kepada Tuhan-mu yang telah menciptakan dari diri yang satu, dan dari padanya Allah menciptakan isterinya; dan dari pada keduanya Allah memperkembang biakkan laki-laki dan perempuan yang banyak. Dan bertaqwalah kepada Allah yang dengan (mempergunakan) namaNya kamu saling meminta satu sama lain, dan (peliharalah) hubungan silaturrahim. Sesungguhnya Allah selalu menjaga dan mengawasi kamu”. (QS An-Nisa: 1)

f. Hak mendapatkan kebutuhan dasar hidup manusia secara tersirat terdapat dalam surat Az-Dzariyat ayat 19, yang berbunyi:

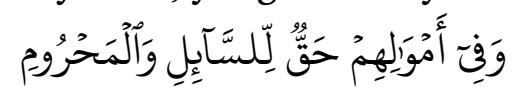

Artinya:

"Dan pada harta-harta mereka ada hak untuk orang miskin yang meminta dan orang miskin yang tidak mendapat bagian”. (QS Az-Dzariyat: 19)

g. Hak mendapatkan pendidikan Islam juga memiliki pengaturan secara tersirat dalam surat Al Mujadilah ayat 11 yang berbunyi:

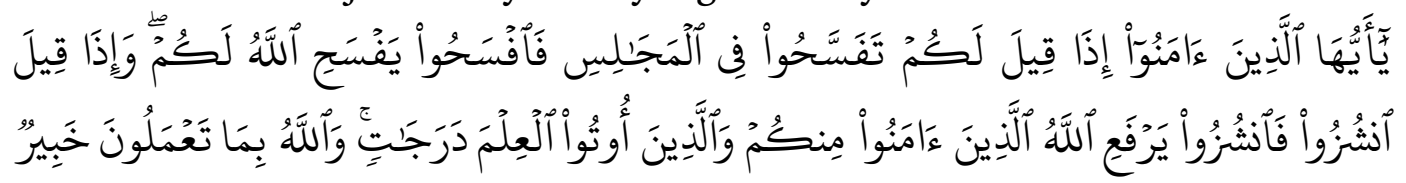

Artinya:

"Hai orang-orang beriman apabila dikatakan kepadamu: "Berlapang-lapanglah dalam majlis", maka lapangkanlah niscaya Allah akan memberi kelapangan untukmu. Dan apabila dikatakan: "Berdirilah kamu", maka berdirilah, niscaya Allah akan meninggikan orang-orang yang beriman di antaramu dan orangorang yang diberi ilmu pengetahuan beberapa derajat. Dan Allah Maha Mengetahui apa yang kamu kerjakan" (Qs Al Mujadilah: 11)

Dalam monokrasi Islam, jaminan perlindungan terhadap nyawa manusia sangat diperhatikan, sebagai tercantum dalam al-Qur'an surah Al-Midah ayat 32 yang dapat ditarik garis hokum yaitu manusia dilarang membunuh sesamanya, kecuali berdasarkan alas an yang dibenarkan hokum Islam yaitu qishas. Menghilangkan nyawa orang lain tanpa alas an qishas itu wajib dijatuhi hukuman mati atau pidana mati. Suatu tindak pidana pembunuhan dalam ayat 
ini diumpamakan bahwa seorang pembunuh seakan-akan telah melakikan pembunuhan terhadap seluruh manusia.

Logika al-Qur'an di sini terletak pada bahwa manusia itu adalah anggota masyarakat dan membunuh seorang masyarakat berarti juga membunuh keturunannya, karena itu dalam hokum pidana Islam, hukuman mati yang wajib dijalankan kecuali apabila keluarga korban memafkannya.

Hak untuk hidup dan hak atas perlindungan untuk hidup berkaitan erat dengan keselamatan pribadi manusia dan kebebasannya. Tentang kebebasan manusia dalam nomokrasi Islam sekurang-kurangnya ada lima kebebasan yang dapat dianggap sebagai hak-hak dasar manusia. Lima macam kebebasan itu adalah :

1. Kebebasan agama

2. Kebebasan berpikir dan menyatakan pendapat sebagai buah pikirannya

3. Kebebasan untuk memilih harta benda

4. Kebebasan untuk berusaha dan memilih pekerjaan, dan

5. kebebasan untuk memilih kedamaian.

Lima macam kebebasan tersebut di atas bukan hanya diakui tetapi juga wajib dilindungi dalam negara hokum menurut al-Qur'an dan Sunnah.

\section{Aspek perlindungan HAM dalam Pidana Islam}

Agama dengan tiga rukunnya, yakni iman, Islam, dan ihsan atau akidah, syari'at, dan akhlak adalah murni diperuntukkan kepada umat manusia. Tidak ada sedikitpun kepentingan Tuhan yang menurunkannya, karena Allah SWT memang tidak punya kepentingan sekecil apapun. Karena itu, setiap ketentuan agama, termasuk hukum pidanya akan bertumpu pada pemenuhan serta perlindungan hak dan kepentingan manusia.

Kalangan para ulama dikenal apa yang disebut Maqashidusy Syai'at, yaitu tujuan hukum Islam yang mencakup perlindungan terhadap lima hal yang menjadi tonggak keberadaan manusia, yakni agama (akidah), nyawa, akal, nasab atau harga diri, dan harta benda. Dengan demikian, sebenarnya pertanyaan sejauh manakah hukum pidana Islam dapat melindungi hak-hak asasi manusia tidak perlu muncul ditengah umat yang meyakini kebenaran agama tersebut.

Namun akhirnya, pertanyaan tersebut menemukan relevansinya karena didukung oleh factor, di antaranya yang terpenting ialah (1) perbedaan pandangan antara agama dan pandangan umum yang berkembang dalam melihat HAM serta dasar filosofisnya; dan (2) perhatian terhadap Islam yang menitikberatkan pada hokum pidananya. Kedua factor ini bukan saja melahirkan tanda Tanya bagi sementara orang tentang kaitan hokum pidana Islam dengan HAM, bahkan telah melahirkan sikap apriori dari sebagian umat Islam sendiri terhadap hukum Islam secara keseluruhan.

Islam menyatakan secara eksplisit sangat menghormati harkat manusia adalah jelas. Namun, dalam melihat manusia, Al-Qur'an telah menggabungkan dua sisi yang bertolak belakang dari makhluk ini. Manusia dianggap sebagai makhluk yang sangat mulia, tetapi pada saat yang sama ia juga dianggap sebagai makhluk yang sangat hina. 
Kedua sisi manusia yang bertolak belakang itu juga diterjemahkan oleh agama melalui tatanan hukumnya. Ketika seorang manusia tidak bersalah, maka hak dan martabatnya dianggap suci dan harus dilindungi secara penuh. Sebaliknya, ketika kesalahan seseorang sampai pada kejahatan qishas atau hudud, maka satu persatu dari sendi-sendi kemuliaannya itu runtuh, kemudian diperlakukan oleh hokum berdasarkan sisi kehinaannya.

Ia tidak lagi dipandang sebagai anggota masyarakat yang berguna, tetapi sebaliknya, ia ibarat anggota tubuh yang terpaksa harus diamputasi demi keselamatan tubuh itu sendiri. Karena itu, al-Qur'an melarang kita menaruh rasa iba kepada pezina yang dijatuhi hukuman cambuk (an-Nur:2) karena ia memang tidak lagi berhak mendapatkan rasa iba.

Dengan demikian, keluarlah anggapan bahwa sanksi dan hukuman pidana Islam (hukuman mati, potong tangan, cambuk) kejam atau tidak manusiawi. Hal ini dikarenakan tidak adanya keyakinan akan sisi kehinaan manusia, sehingga ia dipandang sebagai makhluk yang mulia selamanya dalam keadaan apa saja.

Dengan menggabungkan dua sisi manusia yang bertolak belakang itu, maka hukuman pidana Islam boleh saja dikatakan keras dan berat, tetapi kekerasan itu dijatuhkan kepada orang yang telah dilucuti martabat kemanusiaannya. Maka, penerapannya tidak dapat dikatakan bertentangan dengan perlindungan HAM, tetapi justru di situlah terdapat salah satu bentuk penegakan HAM.

Sementara itu, hokum Islam mempunyai pandangan yang berbeda. Menurut hokum Islam, akidah yang benar adalah kebutuhan yang sangat vital. Melebihi kebutuhan terhadap makanan dan minuman. Dengan akidah, seseorang bisa hidup secara ruhani. Sementara makanan hanya membuatnya hidup secara jasmani (al-An'am: 123). Akidah bagaikan mata air yang dibutuhkan setiap orang, harus diberi kebebasan mengalir. Tidak boleh seseorang pun menyumbat atau mencemarinya. Jika air itu telah mengalir dan ada orang-orang yang tidak mau meminumnya, maka hal itu menjadi hak mereka.

\section{Kesimpulan}

Dari pembahasan diatas, dapat disimpulkan bahwa Islam mengandung pengaturan mengenai HAM secara tersirat. Pertama, Hak asasi manusia dalam Islam terbagi atas Hak atas hidup, hak untuk mendapat perlindungan dari hukuman yang sewenang wenang, hak atas keamanan dan kemerdekaan pribadi, hak atas kebebasan beragama memilih keyakinan berdasar hati nurani, hak kebebasan berserikat, hak mendapatkan kebutuhan dasar hidup manusia, hak mendapatkan pendidikan Islam. Kedua, HAM dalam Islam sangat diperhatikan sehingga sebagai umat Islam yang selalu melaksanakan ajaran yang baik, hendaknya kita selalu menghormati hak-hak orang lain dan juga hendaknya kita harusterus mempelajari secara mendalam pengetahuan kita tentang HAM 


\section{Daftar Pustaka}

Bambang Suteng. 2006. Pendidikan Kewarganegaraan. Jakarta: Erlangga.

Hafniati. 2018. Hak Azasi Manusia Dalam Islam. Jurnal Al-Adyan, Volume 13, No. 2, Juli-Desember.

Kementrian Agama RI. 2010. Al-Qur'an dan Tafsirnya. Jakarta: Lentera Abadi.

Mahmud. 2011. Metode Penelitian Pendidikan. Bandung: pustaka setia

Maisaroh. 2015. Islam dan Hak Azasi Manusia. Jurnal Islamuna Jurnal Studi Islam, Vol 2 No 2

Siti Aminah. 2010. Hak Asasi Manusia (Ham) Dalam Perspektif Alquran. Jurnal Hukum Diktum, Volume 8, Nomor 2, Juli 2010, hlm 161-173.

Urbaningrum, Anas. 2004. Islam-Demokrasi Pemikiran Nurcholish Majid, Jakata. Republika. 

E-ISSN : 2685-399X 